\title{
Geochemical typification of Early Cambrian magmatism of the northeast of the Siberian platform (Neleger river area)
}

\author{
A.D. SAVELEV ${ }^{1,2 *}$, S.V. MALYSheV ${ }^{2}$, A. A. PAZUKhinA ${ }^{2}$
}

${ }^{1}$ Tomsk State University, 36, Lenin Ave., Tomsk, 634050, Russian Federation (*correspondence: aleksandr.d.savelev@gmail.com)

${ }^{2}$ St. Petersburg State University, 7-9, Universitetskaya nab., St. Petersburg, 199034, Russian Federation

The Early Cambrian mafic magmatism commonly known as the Kharaulakh event has been documented in the northeast of the Siberian platform in the Olenek uplift and in the frontal thrust sheets of the Verkhoyansk fold-and-thrust belt in the Kharaulakh Mountains. Intrusions of the Kharaulakh event are sills that typically cut Neoproterozoic succession.

The uppermost magmatic body is located within the lowermost Cambrian sedimentary rocks and is interpreted to be a volcanic flow. U-Pb age of pebbles ranges from 545 to 525 Ma showing that duration of the Kharaulakh eventrelated magmatism was close to $20 \mathrm{My}[1,2]$.

Neleger sills are enriched in titanium with $\mathrm{TiO}_{2}$ ranging from $3.6 \%$ to $6.3 \%$. Studied magmatic rocks have very similar patterns when plotted on the mantle-normalized multy-element diagram and follow OIB trend. Sills confined to the bottom part of the section (Neleger and Siatachan formations) are characterized by positive $\mathrm{Ti}, \mathrm{P}$ and $\mathrm{Eu}$ anomalies. Identified higher concentrations of $\mathrm{V}$ as well as lower concentrations of $\mathrm{SiO}_{2}$ and $\mathrm{Al}_{2} \mathrm{O}_{3}$ compared to the bodies from the upper formation (Kharayutekh). Values of $\varepsilon N d(T)$ varies from 2.2 to 4.5 and doesn't have any ordering.

Such chemical compositions of the basaltic magma are typical for the continental rifts, and Kharaulakh event correlates well with the latest Neoproterozoic - Early Cambrian rifting of the south-east margin of the Siberian platform. Gradual variation in chemical composition of the intrusions is typical for magma formed at the different stages of rift evolution, likely pointing that sills localized in the lower part of the section are the earlier phases of the magmatic event.

This study was supported by the Geochronological (Sm$\mathrm{Nd}$ and $\mathrm{Rb}$-Sr isotopes) research has been carried out within the grant of the Russian Science Foundation (project № 1817-00240).

[1] Khudoley et al. (2013) Lithos 174, 44-56. [2] Prokopiev et al. (2016) Russian Geology and Geophysics 57, 155-175 